\title{
Expression and Significance of Hepatitis $B$ Virus $X$ Protein and Hepatitis B Virus DNA Levels in Renal Tissue of Patients with Glomerulonephritis and Hepatitis B Virus Infection
}

AIHUA MA, CHENGZHEN ZHANG ${ }^{1}$ AND HUI LI ${ }^{1 *}$

Infection Group of Respiratory Medicine, ${ }^{1}$ Department of Nephrology, 80th Group Army Hospital of the Chinese People's Liberation Army, No.256 West Street, Bei Gong, Weifang 261041, Shandong, China

Ma et al.: Significance of HBX Protein and HBV-DNA Levels in Patients with Glomerulonephritis and HBV Infection

\begin{abstract}
To investigate the expression and clinical significance of hepatitis $B$ virus $X$ protein and hepatitis $B$ virus deoxyribonucleic acid in hepatitis B virus associated nephritis. 78 patients with hepatitis $B$ virus associated nephritis treated in our hospital from January 2018 to January 2020 were selected as observation group. At the same time, 70 patients with nephritis with positive hepatitis B markers but without hepatitis B surface antigen and/or hepatitis $B$ core antigen deposition in renal tissue were selected as the control group. The clinical data, hepatitis $B$ virus $X$ protein and hepatitis $B$ virus deoxyribonucleic acid were compared between the two groups. There was no significant difference in white blood cells, red blood cells, platelet count test, activated partial thromboplastin time, prothrombin time between the observation group and the control group $(\mathrm{p}>\mathbf{0 . 0 5})$. The positive rate of hepatitis $B$ virus $X$ protein and the proportion of hepatitis $B$ virus deoxyribonucleic acid $>105 \mathrm{IU} / \mathrm{ml}$ in the observation group were $61.54 \%, 89.74 \%$ and $52.56 \%$ respectively, which were significantly higher than those in the control group $(\mathbf{p}<0.05)$. The proportion of 'Xiaosanyang' and hepatitis B virus deoxyribonucleic acid $<103 \mathrm{IU} / \mathrm{ml}$ were $32.05 \%$ and $11.54 \%$ respectively, which were significantly lower than those in the control group $(\mathbf{p}<0.05)$. The proportion of hepatitis B virus deoxyribonucleic acid quantification $>105 \mathrm{IU} / \mathrm{ml}$ in the observation group was $62.50 \%$, which was significantly higher than that in the non-three-positive patients $(p<0.05)$. The proportion of patients with hepatitis $B$ virus deoxyribonucleic acid quantification $>105 \mathrm{IU} / \mathrm{ml}$ in the observation group was $76.00 \%$, which was significantly higher than that in patients with effective treatment $(p<0.05)$. The levels of hepatitis B virus $X$ protein and hepatitis B virus deoxyribonucleic acid in patients with hepatitis B virus-associated nephritis were higher and the level of hepatitis $B$ virus deoxyribonucleic acid was related to Sanyang and therapeutic effect, but hepatitis B virus X protein was not significantly correlated.
\end{abstract}

Key words: Hepatitis $B$ virus $X$ protein, hepatitis $B$ virus DNA, hepatitis $B$ virus associated glomerulonephritis, clinical significance

High incidence of hepatitis B virus infection in Chinese people, can cause hepatitis B virus associated nephritis, the specific pathogenesis is not yet fully clear. It has been reported that hepatitis $B$ virus intact virus particles exist in glomeruli and hepatitis B virus DNA (HBVDNA) can also be detected in glomeruli and renal cortex, suggesting that hepatitis $B$ virus replication has a direct effect on renal tissue ${ }^{[1]}$. There are different clinical reports on evaluation indexes of hepatitis $B$ virus associated nephritis. Hepatitis B virus $\mathrm{X}(\mathrm{HBX})$ protein is encoded by $X$ protein gene and has transactivation effect, which can activate transcription factors to cause nuclear translocation and promote the occurrence and development of inflammation. HBVDNA is a cyclic DNA molecule with incomplete double strands and its sequence is highly conserved. It is a basic viral protein in the viral infection cycle of the body, mainly located in the host cytoplasm. However, the clinical reports on the changes of two proteins in patients with hepatitis $B$ virus-associated nephritis and

*Address for correspondence

E-mail: lihui32298@163.com 
the evaluation of therapeutic effect are relatively rare ${ }^{[2]}$. In this study, the expression of HBX protein and HBVDNA in hepatitis B virus-associated glomerulonephritis and the evaluation of therapeutic effect were analyzed. The results are reported as follows. 78 patients with hepatitis B virus associated nephritis treated in our hospital from January 2018 to January 2020 were selected as observation group. At the same time, 70 patients with nephritis with positive hepatitis B markers but without Hepatitis B surface antigen (HBsAg) and/or Hepatitis B core antigen ( $\mathrm{HBcAg}$ ) deposition in renal tissue were selected as the control group. There was no significant difference in gender and age between the observation group and the control group ( $>0.05$ ). Inclusion criteria-Renal biopsy was performed in our hospital; Age $>18 \mathrm{y}$; Patients and their families informed consent. Exclusion criteriaCombined with hepatitis $\mathrm{C}$ virus and other hepatitis virus infection; There are lupus nephritis, purpura nephritis, diabetic nephropathy, tumor associated nephritis, hypertensive nephropathy, etc. HBV-DNA level determination-Take $0.5 \mathrm{~mL}$ centrifuge tube to mark and add $100 \mu \mathrm{l}$ cracking liquid that has been fully shaken to each centrifuge tube, then add $50 \mu \mathrm{L}$ specimens or standards to each centrifuge tube, after vortex mixing, placed at room temperature for $10 \mathrm{~min}$; Centrifuge $10000 \mathrm{rpm}$ for $25 \mathrm{~s}$, pour the supernatant, adding detergent $150 \mu \mathrm{L}$, fully vortex mixing, again centrifuge $1000 \mathrm{rpm}$ for $25 \mathrm{~s}$, pour the supernatant, again adding repeated detergent $150 \mu \mathrm{L}$, fully vortex mixing, centrifuge $10000 \mathrm{rpm}$ for $25 \mathrm{~s}$, discard the supernatant to be measured. Add $30 \mu \mathrm{L}$ reaction buffer to the prepared precipitate and suspension evenly, take $25 \mathrm{uL}$ to each reaction tube, suspended evenly and centrifuged slightly, then placed in the fluorescence PCR amplification instrument, cycle conditions: $38^{\circ}$ $5 \mathrm{~min}, 95^{\circ} 10 \mathrm{~min}$. Enter the following cycle: $95^{\circ} 15 \mathrm{~s}$, $58^{\circ} 50 \mathrm{~s}$ (read fluorescence after $30 \mathrm{~s}$ ), 40 cycles. The automatic medical polymerase chain reaction (PCR) analysis system was used for analysis. The fluorescence signals of 1-10 cycles were selected as the baseline. The setting principle of the threshold was that the threshold line was just slightly higher than the highest point of the amplification curve of the normal negative control. Determination of HBX protein-Paraffin sections of kidney tissue $(3 \mu \mathrm{m})$ were dewaxed and placed in water and stained with En Vision two-step method. EDTA ( $\mathrm{pH}$ 8.0) repair solution was used for high-pressure repair antigen and rabbit polyclonal AntiHBX antibody was added and incubated overnight at $4^{\circ}$. The corresponding secondary antibody labeled with biotin was added, incubated at $4^{\circ}$ for 20 min, washed with buffer for 2-3 times and stained with 3,3'-Diaminobenzidine (DAB), dehydrated, transparent and sealed. 20 visual fields were randomly selected for each image and 0-3+ were set from negative to the strongest. The negative control was set: phosphate buffer (PBS) instead of primary antibody. Tenofovir dipivoxil combined with Compound Yiganling Tablets was given $300 \mathrm{mg} /$ time, once daily for $6 \mathrm{mo}$. Compound Yiganling Tablets 4 tablets/time, 3 times/d, continuous treatment for 6 mo. The basic treatment of all patients was collected and the patients were followed up for 6 mo. The collected data were input into the computer system and analyzed. Judgment of therapeutic effect ${ }^{[3]}{ }_{-}$ Effectively, the urinary protein of patients was decreased by $\geq 50 \%$ compared with that before treatment, albumin (ALB) was increased and $\geq 30 \mathrm{~g} / \mathrm{L}$, alanine aminotransferase (ALT) and HBV-DNA were decreased by $\geq 50 \%$ compared with that before treatment, and the symptoms and signs were relieved. Failure to meet the above standards. Statistical package for social sciences (SPSS) 22.0 software was used. Measurement data were expressed as $(\mathrm{x} \pm \mathrm{s})$ and $\mathrm{t}$ test was used to analyze the difference between groups. Count data using frequency or percentage, $\chi^{2}$ test analysis between groups differences; $\alpha=0.05$, Table 1 . There was no significant difference in white blood cells (WBC), red blood cells (RBC), platelet count test (PLT), activated partial thromboplastin time (APTT), prothrombin time (PT), ALT, AST between the observation group and the control group ( $>0.05)$. See Table 2 . The positive rate of HBX protein and the proportion of HBV-DNA $>105$ $\mathrm{IU} / \mathrm{ml}$ in the observation group were significantly higher than those in the control group $(\mathrm{p}<0.05)$, while the proportion of HBX protein and HBV-DNA $<103$ $\mathrm{IU} / \mathrm{ml}$ in the observation group were significantly lower than those in the control group $(\mathrm{p}<0.05)$. See Table 3 . There was no significant difference in gender, age, body mass index and positive rate of HBX protein between the patients with and without Sanyang in the observation group ( $p>0.05)$. The proportion of HBV-DNA $>105 \mathrm{IU} /$

\begin{tabular}{|c|c|c|c|c|}
\hline Group & cases & $\begin{array}{c}\text { Male/ } \\
\text { female }\end{array}$ & Age (y) & $\begin{array}{l}\text { Body mass index } \\
\left(\mathrm{kg} / \mathrm{m}^{2}\right)\end{array}$ \\
\hline $\begin{array}{l}\text { observation } \\
\text { group }\end{array}$ & 78 & $48 / 30$ & $45.50 \pm 9.97$ & $22.45 \pm 3.36$ \\
\hline $\begin{array}{l}\text { control } \\
\text { group }\end{array}$ & 70 & $41 / 29$ & $43.84 \pm 10.15$ & $21.97 \pm 2.95$ \\
\hline $\mathrm{t}$ & & 0.135 & 1.003 & 0.919 \\
\hline $\mathrm{p}$ & & 0.713 & 0.318 & 0.360 \\
\hline
\end{tabular}


TABLE 2: COMPARISON OF BLOOD ROUTINEAND BIOCHEMICAL INDEXES BETWEEN THE OBSERVATION GROUP AND THE CONTROL GROUP

\begin{tabular}{lcccc}
\hline Index & $\begin{array}{c}\text { observation group } \\
(\mathbf{n}=\mathbf{7 8})\end{array}$ & $\begin{array}{c}\text { control group } \\
(\mathbf{n}=70)\end{array}$ & $\mathbf{t} / \chi^{2}$ & $\mathrm{p}$ \\
\hline WBC $\left(\times 10^{9} / \mathrm{L}\right)$ & $6.45 \pm 1.12$ & $6.80 \pm 1.21$ & -1.827 & 0.070 \\
RBC $\left(\times 10^{12} / \mathrm{L}\right)$ & $4.42 \pm 0.97$ & $4.55 \pm 0.91$ & -0.838 & 0.403 \\
PLT $\left(\times 10^{9} / \mathrm{L}\right)$ & $199.78 \pm 33.87$ & $202.45 \pm 36.68$ & -0.460 & 0.646 \\
APTT $(\mathrm{s})$ & $32.10 \pm 6.10$ & $33.15 \pm 6.87$ & -0.985 & 0.326 \\
PT $(\mathrm{s})$ & $11.65 \pm 3.31$ & $11.42 \pm 3.28$ & 0.424 & 0.672 \\
ALT $(\mathrm{U} / \mathrm{L})$ & $32.29 \pm 9.97$ & $30.87 \pm 8.11$ & 0.944 & 0.347 \\
AST $(\mathrm{U} / \mathrm{L})$ & $36.61 \pm 10.05$ & $34.48 \pm 11.17$ & 1.221 & 0.224 \\
GGT $(\mathrm{U} / \mathrm{L})$ & $48.84 \pm 16.67$ & $45.56 \pm 17.19$ & 1.178 & 0.241 \\
ALB $(\mathrm{g} / \mathrm{L})$ & $21.45 \pm 2.15$ & $20.87 \pm 2.25$ & 1.603 & 0.111 \\
TBIL $(\mathrm{mol} / \mathrm{L})$ & $9.41 \pm 2.03$ & $9.69 \pm 1.94$ & -0.855 & 0.394 \\
DBIL $(\mathrm{mol} / \mathrm{L})$ & $2.60 \pm 0.95$ & $2.71 \pm 0.96$ & -0.700 & 0.485 \\
BUN $(\mathrm{mol} / \mathrm{L})$ & $6.61 \pm 1.12$ & $6.40 \pm 1.09$ & 1.153 & 0.251 \\
SCr $(\mathrm{mol} / \mathrm{L})$ & $76.65 \pm 10.15$ & $80.15 \pm 12.21$ & -1.903 & 0.059 \\
24h urinary protein quantification $(\mathrm{g})$ & $4.82 \pm 0.99$ & $4.76 \pm 1.00$ & 0.366 & 0.715 \\
\hline
\end{tabular}

TABLE 3: COMPARISON OF HBV MARKERS, HBX AND HBV-DNA BETWEEN OBSERVATION GROUP AND CONTROL GROUP

\begin{tabular}{lcccc}
\hline Index & $\begin{array}{c}\text { observation group } \\
(\mathbf{n}=\mathbf{7 8})\end{array}$ & control group $(\mathrm{n}=\mathbf{7 0})$ & $\mathrm{t} / \chi^{2}$ & $\mathrm{p}$ \\
\hline Big three positive & $48(61.54)$ & $18(25.71)$ & 19.162 & 0.000 \\
Small three positive & $25(32.05)$ & $50(71.43)$ & 22.886 & 0.000 \\
other & $5(6.41)$ & $2(2.86)$ & 0.395 & 0.529 \\
HBx protein positive rate (\%) & $70(89.74)$ & $45(64.29)$ & 13.800 & 0.000 \\
HBV-DNA quantification (IU/ & & & & \\
ml) & $9(11.54)$ & $29(41.43)$ & 17.272 & 0.000 \\
$<10^{3}$ & $28(35.90)$ & $30(42.86)$ & 0.750 & 0.387 \\
$10^{3} \sim 10^{5}$ & $41(52.56)$ & $11(15.71)$ & 21.981 & 0.000 \\
$>10^{5}$ & & & & \\
\hline
\end{tabular}

Note: Big three positive: $\mathrm{HBsAg}, \mathrm{HBeAg}, \mathrm{HBcAb}$ positive; small three positive: $\mathrm{HBsAg}, \mathrm{HBeAb}, \mathrm{HBCAb}$ positive.

TABLE 4: COMPARISON OF HBX AND HBV-DNA IN PATIENTS WITH BIG THREE POSITIVE AND NON BIG THREE POSITIVE IN OBSERVATION GROUP

\begin{tabular}{lcccc}
\hline Index & $\begin{array}{c}\text { Big three positive } \\
(\mathbf{n}=48)\end{array}$ & $\begin{array}{c}\text { Non big three positive } \\
(\mathbf{n}=30)\end{array}$ & $\mathrm{t} / \chi^{2}$ & $\mathrm{p}$ \\
\hline Sex & $30(62.50)$ & $18(60.00)$ & & \\
Male & $18(37.50)$ & $12(40.00)$ & 0.049 & 0.825 \\
Female & $46.20 \pm 9.72$ & $44.38 \pm 10.15$ & 0.791 & 0.431 \\
Age $(\mathrm{y})$ & $22.29 \pm 2.81$ & $22.71 \pm 3.00$ & -0.626 & 0.533 \\
body mass index $\left(\mathrm{kg} / \mathrm{m}^{2}\right)$ & $45(93.75)$ & $25(83.33)$ & 1.192 & 0.275 \\
HBX Protein positive rate $(\%)$ & & & & \\
HBV-DNA quantification & $3(6.25)$ & $7(23.33)$ & 3.413 & 0.065 \\
$<10^{3}$ & $15(31.25)$ & $12(40.00)$ & 0.625 & 0.429 \\
$10^{3} \sim 10^{5}$ & $30(62.50)$ & $11(36.67)$ & 4.941 & 0.026 \\
$>10^{5}$ & & &
\end{tabular}

$\mathrm{ml}$ in the observation group was significantly higher than that in the non-three positive patients $(\mathrm{p}<0.05)$. See Table 4. The proportion of HBV-DNA quantification $>105 \mathrm{IU} / \mathrm{ml}$ in the observation group was $76.00 \%$, which was significantly higher than that in the patients with effective treatment $(\mathrm{p}<0.05)$. There was no significant difference in gender, age, body mass index, hepatitis B marker phenotype and positive rate of HBX protein between ineffective and effective patients in the observation group $(p>0.05)$. See Table 5. Hepatitis B virus associated nephritis is a kind of immune complex renal disease caused by hepatitis B virus directly or 
TABLE 5: COMPARISON OF HBX AND HBV-DNA BETWEEN EFFECTIVE AND INEFFECTIVE PATIENTS IN THE OBSERVATION GROUP

\begin{tabular}{|c|c|c|c|c|}
\hline Index & Effective $(n=53)$ & Ineffective $(n=25)$ & $t / \chi^{2}$ & $\mathrm{p}$ \\
\hline \multicolumn{5}{|l|}{ Sex } \\
\hline Male & $31(58.49)$ & $17(68.00)$ & \multirow{2}{*}{0.649} & \multirow{2}{*}{0.420} \\
\hline Female & $22(41.51)$ & $8(32.00)$ & & \\
\hline Age $(y)$ & $46.03 \pm 8.12$ & $44.65 \pm 9.12$ & 0.673 & 0.503 \\
\hline body mass index $\left(\mathrm{kg} / \mathrm{m}^{2}\right)$ & $22.17 \pm 3.03$ & $22.90 \pm 3.16$ & -0.980 & 0.330 \\
\hline \multicolumn{5}{|l|}{ Hepatitis B marker phenotype } \\
\hline big three positive & $33(62.26)$ & $16(64.00)$ & \multirow{2}{*}{0.022} & \multirow{2}{*}{0.882} \\
\hline Non big three positive & $20(37.74)$ & $9(36.00)$ & & \\
\hline HBX Protein positive rate (\%) & $46(86.79)$ & $24(96.00)$ & 0.724 & 0.395 \\
\hline \multicolumn{5}{|l|}{ HBV-DNA quantification } \\
\hline$<10^{3}$ & $9(16.98)$ & $1(4.00)$ & 1.531 & 0.216 \\
\hline $10^{3} \sim 10^{5}$ & $22(41.51)$ & $5(20.00)$ & 3.472 & 0.062 \\
\hline$>10^{5}$ & $22(41.51)$ & $19(76.00)$ & 8.104 & 0.004 \\
\hline
\end{tabular}

indirectly. Its diagnosis requires renal biopsy and serum immunology. Mild hematuria, proteinuria and nephrotic syndrome are the main clinical manifestations of most patients with hepatitis B virus associated nephritis ${ }^{[4]}$. At present, the specific mechanism of this disease is not clear. Some studies believe that the accumulation of HBV antigen-antibody complexes in the glomerular site causes the immune loss of the body, which leads to the occurrence and development of this disease. It mainly exists in two forms: circulating immune complexes and in situ immune complexes. Some scholars believe that the virus directly infects kidney cells and causes kidney damage. The pantropism of HBV can directly infect kidneys, destroy kidney cells and cause death ${ }^{[5]}$. HBV virus can activate the apoptosis pathway in vivo to induce apoptosis, change the expression of podocyte surface markers, activate cellular immunity, promote the synthesis and release of cytokines, and cause local immune response ${ }^{[6]}$. At present, the coexistence of HBV infection and immunemediated inflammation leads to difficult treatment. There is no unified and clear treatment plan at present. The main principle of clinical treatment is to reduce urinary protein, protect liver and kidney function, slow down the progress of the disease and prevent the recurrence of the disease ${ }^{[7]}$. Studies have shown that inhibition of HBV-DNA replication and effective clearance of $\mathrm{HBe} \mathrm{Ag}$ can reduce proteinuria, even negative and improve renal function in patients with HBV-related nephropathy ${ }^{[8]}$. This study analyzed the expression of hepatitis $B$ virus $\mathrm{X}(\mathrm{HBX})$ protein and hepatitis B virus DNA (HBV-DNA) in hepatitis B virus associated nephritis and its role in clinical treatment evaluation. HBX protein is one of the basic viral proteins in the viral infection cycle in vivo and is one of the indispensable proteins for virus replication in vivo. Animal experiments showed that the replication of HBV in liver cells in mice with cancer was dependent on the expression of X protein. HBX protein had a wide range of effects on the proliferation of glomerular mesangial cells, the apoptosis of podocytes and renal tubular epithelial cells ${ }^{[9-10]}$. Some scholars have found that HBX protein is closely related to the occurrence and development of renal diseases. The positive rate of HBV-DNA expression in renal tissues with $\mathrm{HBV}$ serological positive detection by in situ hybridization is $88.9 \%$ and the distribution of cytoplasm in renal tubular epithelial cells is consistent with that of HBVAg positive particles in tissues ${ }^{[11-12]}$. HBV gene is a circular DNA molecule with incomplete double-stranded, highly conserved sequence is the basic viral protein in the virus infection cycle in vivo, mainly located in the host cytoplasm, a small part in the nucleus ${ }^{[13]}$. Quantitative detection of HBV-DNA can reflect the replication of $\mathrm{HBV}$ virus and the level of $\mathrm{HBV}$ in serum. In this study, the proportion of HBV-DNA > $105 \mathrm{IU} / \mathrm{ml}$ in patients with triple positive was significantly higher than that in patients with non-triple positive and after active treatment, HBV-DNA was significantly decreased, indicating that the status of viral replication and viral load after HBV infection are related to the occurrence of this disease, consistent with previous studies $^{[14-15]}$. This also suggests that the clinical HBe Ag positive, HBV-DNA quantitative higher patients, should actively anti-HBV treatment, maximum inhibition of viral replication. The results showed that the positive rates of HBX protein and HBV-DNA > 105 $\mathrm{IU} / \mathrm{ml}$ in the observation group were significantly higher than those in the control group, while the positive rates of HBX protein and HBV-DNA $<103 \mathrm{IU} / \mathrm{ml}$ in the 
observation group were significantly lower than those in the control group. It is suggested that the positive rate of 'three positive' and HBX protein and the proportion of HBV-DNA $>105 \mathrm{IU} / \mathrm{ml}$ in patients with hepatitis B virus associated nephritis are significantly increased, suggesting that viral replication is more significant. The proportion of HBV-DNA >105 IU/ml in the observation group was significantly higher than that in the non-three positive patients, suggesting that the viral load in patients with hepatitis B virusassociated nephritis was higher. Through active and effective treatment, the proportion of patients with HBV-DNA $>105 \mathrm{IU} / \mathrm{ml}$ in the observation group was $76 \%$, through active and effective treatment, the proportion of patients with HBV-DNA quantification $>105 \mathrm{IU} / \mathrm{ml}$ in the observation group was $76.00 \%$, which was significantly higher than that of patients with effective treatment, suggesting that the level of HBV-DNA was related to the clinical therapeutic effect. The higher the proportion of patients with HBV-DNA quantification $>105 \mathrm{IU} / \mathrm{ml}$, the worse the therapeutic effect. This study analyzed the expression of HBX protein and HBV-DNA quantification in patients with hepatitis B virus-associated nephritis, and confirmed that the level of HBV-DNA had a certain relationship with clinical efficacy, which provided a certain basis for clinical rational evaluation of clinical efficacy. However, the number of patients included in this study was small and the specificity and sensitivity analysis was not carried out. Therefore, it is necessary to further expand the sample size and prolong the follow-up time. In summary, the levels of HBX protein and HBV-DNA in patients with hepatitis $B$ virus-associated glomerulonephritis were relatively high and the level of HBV-DNA was related to Dasanyang and therapeutic efficacy, while HBX protein was not significantly correlated.

\section{Conflict of interests:}

The authors declared no conflicts of interest.

\section{REFERENCES}

1. Li Y, He Y, Yang F. A preliminary study on the correlation between viral replication of chronic hepatitis B virus infection and endoplasmic reticulum stress response in hepatocytes. Adv Mod Biomed 2019;19(04):100-5.

2. Wang Z, Wang T, Su J. Study on the correlation between hepatitis
B virus HBV-LP and HBV replication in chronic hepatitis B patients. Chin J Microbiol Immunol 2020;40(02):110-4.

3. Committee of experts on chronic hepatitis B combined with antiviral therapy. Expert consensus on the treatment of chronic hepatitis B combined with antiviral therapy. Chin J Exp Clin Infect 2011;5(2):224-33.

4. Yuan T, Feng R. Progress in the detection and clearance of hepatitis B virus covalently closed ring DNA (ccc DNA). Chin J Microbiol Immunol 2019;39(11):875-9.

5. Gao P, Zhao G. Effect of hepatitis B virus on hepatitis B-associated glomerulonephritis in different ALT conditions. J Nanjing Med Univ 2020;40(04):115-8.

6. Henson JB, Sise ME. The association of hepatitis C infection with the onset of CKD and progression into ESRD. Semin Dial 2019;32(2):108-18.

7. Hunt E, Somers M. Infection-Related Glomerulonephritis. Pediatr Clin North Am 2019;66(1):59-72.

8. Alabdaljabar MS, Al-Hussain TO, Akhtar M, Conca W, Hussein MH. Rituximab-Induced Remission in Epstein-Barr Virus-Associated Glomerulonephritis. Kidney international reports 2020;5(11):2109-13.

9. Pan K, Wang Y, Pan P, Xu G, Mo L, Cao L, et al. The regulatory role of microRNA-mRNA co-expression in hepatitis B virusassociated acute liver failure. Ann Hepatol 2019;18(6):883-92.

10. Alabdaljabar MS, Al-Hussain TO, Akhtar M, Conca W, Hussein MH. Rituximab-Induced Remission in EpsteinBarr Virus- Associated Glomerulonephritis. Kidney Int 2020;5(11):2109-13.

11. Hunt E, Somers M. Infection-Related Glomerulonephritis. Pediatr Clin North Am 2019;66(1):59-72.

12. Duan Z, Li C, Yang Y. Hepatitis B virus $x$ protein antibodies and cytokines in patients with hepatitis $\mathrm{B}$ and liver cancer. Chin J Health Inspect 2020;30(02):68-73.

13. Zhang Y, Qian J, Ding X. miR-146b-5p regulates the biological function of hepatitis B virus-associated glomerulonephritis by targeting PDHB. J Virus 2020;36(06):125-32.

14. Lei Xiaoyan, Chen Xing, Luo Xuan, et al.Correlation Analysis of Changes of T Lymphocyte Subgroup and Multiple Cytokines with Hepatitis B Virus-associated Nephritis in Children[J]. Chin J Pract Pediatr 2020;35(09):700-4.

15. Zhao R, Qi L. Clinical Observation on Treatment of Hepatitis B Virus-associated Nephritis with Five Ester Capsule and Tacrolimus. Hebei Med 2020;026(003):486-90.

This is an open access article distributed under the terms of the Creative Commons Attribution-NonCommercial-ShareAlike 3.0 License, which allows others to remix, tweak, and build upon the work non-commercially, as long as the author is credited and the new creations are licensed under the identical terms

This article was originally published in a special issue,
"Evolutionary Strategies in Biomedical Research and
Pharmaceutical Sciences" Indian J Pharm Sci 2021:83(3)
Spl issue;186-190

